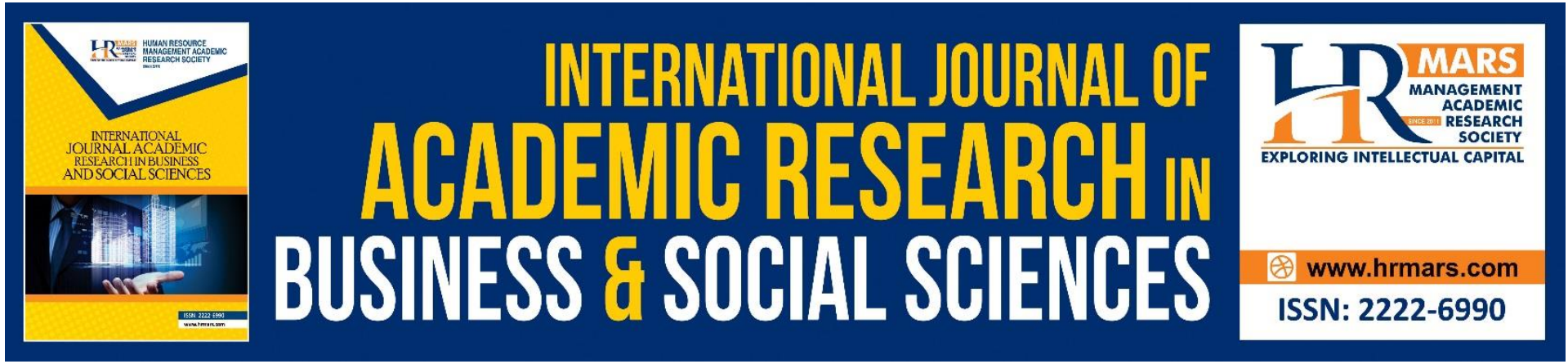

\title{
The Use of Language Learning Strategies to Acquire Listening Skill Among Year 3 ESL Pupils
}

\author{
Visali Vijayaraj, Shevany R K Anumanthan, Ilavarasi Vasu, Pirvita \\ Singgaravi, Harwati Hashim
}

To Link this Article: http://dx.doi.org/10.6007/IJARBSS/v11-i7/10317

DOI:10.6007/IJARBSS/v11-i7/10317

Received: 23 May 2021, Revised: 25 June 2021, Accepted: 06 June 2021

Published Online: 28 July 2021

In-Text Citation: (Vijayaraj et al., 2021)

To Cite this Article: Vijayaraj, V., Anumanthan, S. R. K., Vasu, I., Singgaravi, P., \& Hashim, H. (2021). The Use of Language Learning Strategies to Acquire Listening Skill Among Year 3 ESL Pupils. International Journal of Academic Research in Business and Social Sciences, 11(7), 1069-1079.

Copyright: @ 2021 The Author(s)

Published by Human Resource Management Academic Research Society (www.hrmars.com)

This article is published under the Creative Commons Attribution (CC BY 4.0) license. Anyone may reproduce, distribute, translate and create derivative works of this article (for both commercial and non-commercial purposes), subject to full attribution to the original publication and authors. The full terms of this license may be seen at: http://creativecommons.org/licences/by/4.0/legalcode

Vol. 11, No. 7, 2021, Pg. 1069 - 1079

Full Terms \& Conditions of access and use can be found at http://hrmars.com/index.php/pages/detail/publication-ethics 


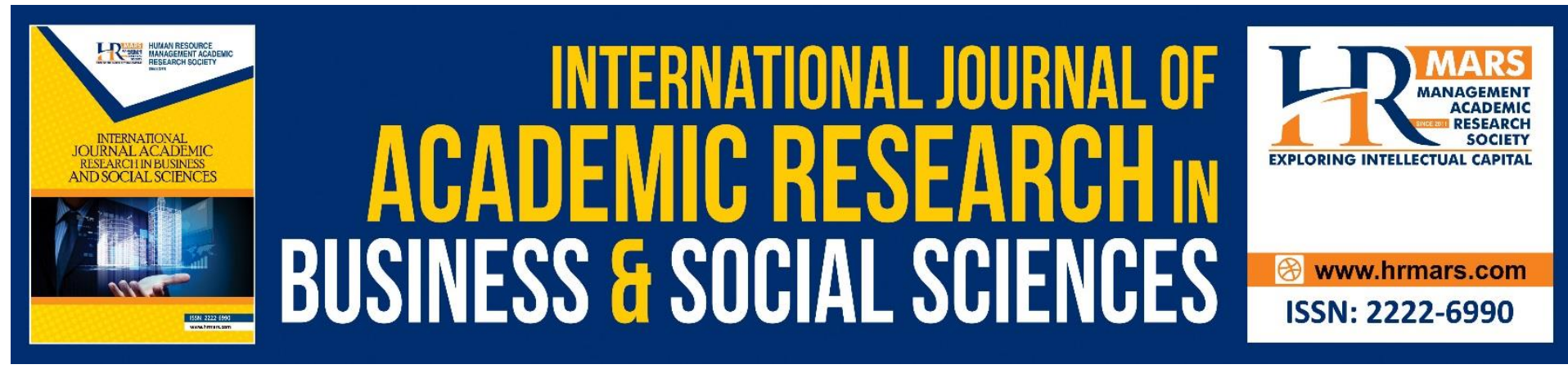

\title{
The Use of Language Learning Strategies to Acquire Listening Skill Among Year 3 ESL Pupils
}

\author{
Visali Vijayaraj, Shevany R K Anumanthan, Ilavarasi Vasu, \\ Pirvita Singgaravi, Harwati Hashim
}

Faculty of Education, Universiti Kebangsaan Malaysia (UKM)

\begin{abstract}
The importance of language learning strategies (LLS) for ESL learners has been revealed in various studies since many years ago. However, very little studies covered the LLS particularly in listening skills among young learners. Thus, the aim of this paper is to investigate the use of language learning strategies to acquire listening skills among year 3 pupils. Quantitative research design was employed for this study where 51 Year 3 students were selected using purposive sampling method. Researchers said the findings of this study showed that pupils prefer cognitive when it comes to direct strategy and affective when it comes to indirect strategy. However, the study also revealed that most of the pupils prefer to listen to songs during lessons to learn a language. It is hoped that the findings could shed lights to teachers and pupils in teaching and learning process as well as adding value to the literature that already exists.
\end{abstract}

Keywords: English as a Second Language (ESL), Language Learning Strategies, Learning English, Listening Skill.

\section{Introduction}

Listening is one of the four language skills (reading, writing, listening, and speaking). It is a mean which people use to communicate with each other to achieve their goals or to express their opinions, intentions, and feelings (Ocak,2012). As language teaching and learning has evolved to more constructivist approach, by identifying the strategies the good learners employ in language learning could give insights on the significance of each strategy used. Literature shows that there are several studies have discovered that the language learners use variety of LLS to enhance their second language learning compared to the less successful learners. Griffiths (2013) stated that language learners need to equip themselves with LLS that will help to enhance their own learning. With the realisation on the importance of investigating learners' LLS, many local researchers have explored further this area of study, such as Ting (2006); Yoong (2010); Aznor \& Razi (2014); Subramanian and Palanisamy (2014). Subramanian and Palanisamy (2014) studied the usage of LLS in private secondary schools; Ting (2006); Yoong (2010) identified LLS used by both successful and unsuccessful secondary school students while Ahmad \& Ismail (2012) investigated the LLS employed by adult ESL learners in Malaysia local university. 
However, the studies mentioned above had only covered the LLS among secondary and tertiary level learners. Little exposure was paid to primary school environments, where it is equally necessary to understand primary school pupils' approach to language learning, since young learners are easier to mould than older learners, and it is hoped that by intervening early, the issue will be addressed at its source (Pandian, 2002). Since ESL learners' study in a context where English is a foreign language rather than a second language, there are few opportunities to practice speaking English. In relation to their English teachers, the learners worry if they would be negatively evaluated (Liu \& Huang, 2011) and the instructors would point out their mistakes to the whole class, which can lead to personal embarrassment to individual learners. However, learners can use many other ways to promote their spoken English. One of them is the use of learning strategies. The rationale behind conducting such investigation is that there are students who excel at reading and writing but they find problems in speaking fluently despite its importance in everyone's career.

Significance of the present study lies in the fact that it investigates the use of strategies not in vocabulary or productive skills as usual, but it aimed at investigating it in a receptive skill which is listening, and this is not common. Autonomous learning and taking charge of one's learning especially in developing listening skills with learning strategies seem to be the main motor responsible for student's English language learning. Therefore, identifying the strategies used by ESL learners will probably help in understanding characteristics of successful English language learners. Therefore, this study is aiming to give information about the learning strategies employed by Year 3 ESL pupils. Information obtained from this study should provide educators with the insights on how good students learn a language and suggest the educators and the state government to come out with a planning that may help the less successful pupils to enhance their listening skill. This will be one of the measures to be taken by the educators to produce successful English language learners and raise the standards of English language proficiency in schools or learning institutions.

\section{Research Objectives}

The research objectives of this study were:

- to identify the frequency of language learning strategies to acquire listening among year 3 ESL pupils.

- to analyse the language learning strategies (LLS) employed by Year 3 pupils to acquire listening skills.

\section{Research Questions}

The study was guided by the following questions:

- To what extent do LLS contribute to the teaching process of Year 3 students and teachers in listening skills?

- What are the language learning strategies (LLS) employed by Year 3 pupils to acquire listening skills?

The remaining of the paper is organised as follows: First, the article reviews the literature, discussing the definitions of LLS and previous studies on LLS. Next, the article describes the participants and instruments involved and present the procedures used to collect the data. This paper will then present and discuss the findings of the study. The article concludes with the implications and recommendations for the teachers. 


\section{Literature Review \\ Language Learning Strategies \\ Definition}

Many scholars have defined the term of Language Learning Strategies. Few scholars stated that LLS is a complex process to acquire a language successfully at the beginning stage for the learners. It seems that LLS undeniably plays a very prominent role to the learner in second language acquisition. According to Oxford (1990), LLS is known as the use of approaches and techniques by language learners to reinforce the progress in developing language skills and learn faster and more enjoyable. On the other hand, Wenden (1991), defines LLS as the efforts put by the learners to master a language successfully. Similarly, Embi (2000) stated LLS can be related to the adequate actions taken by the learners to enhance the language learning processes successfully. He also mentioned that learners use language learning strategies to help them with their major language skills such as listening, speaking, reading and writing.

Apart from that, exposure to a variety of learning approaches tend to make the learners be more motivated in contributing to improving their learning effectively. Although there are many definitions of LLS, it is obviously pretty much around the same fundamental which defines LLS as behaviour, procedure, approval, styles and actions to develop the language skills in a language. Language learning is made easier relying on the interests and learning styles of the learners.

\section{Categorization}

Language Learning Strategies (LLS) is categorized variously by few researchers. As a basis, Oxford's classification was adopted for this research. There are two types of strategies: direct and indirect strategies (Oxford 1990). Oxford (1990) stated direct strategies in the first class primarily require cognitive processes of the target language along with memory strategies, cognitive strategies as well as compensation strategies. Each group of strategies in first class processes the target language differently as well as for different purposes. Besides, the second class is indirect strategies. In the second class, indirect strategies help and manage language learning without engaging the target language. As shown in Figure 1, indirect strategies are classified into three categories such as metacognitive strategies, affective strategies and social strategies. Figure 1 shows Oxford's taxonomy of LLS. In this study, memory strategies, cognitive strategies, compensation strategies, and metacognitive strategies were chosen to evaluate the language learning strategy in listening skill.

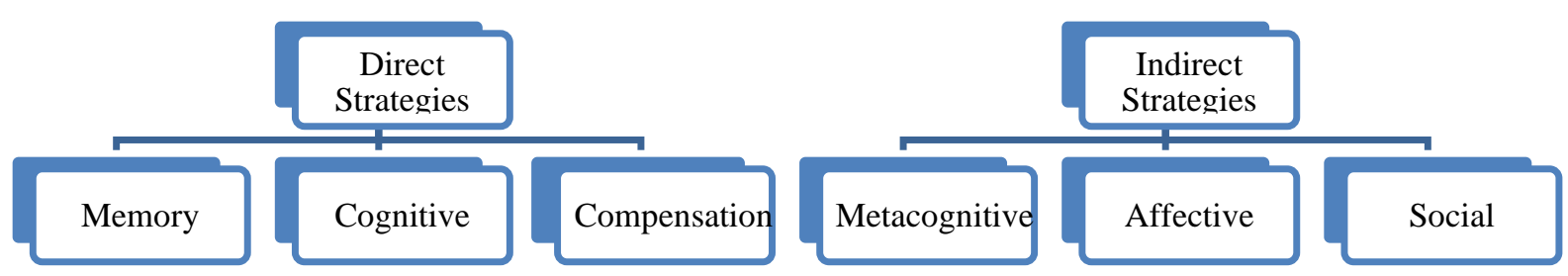

Figure 1: Oxford's (1997): Taxonomy of Language Learning Strategies 


\section{Previous Researches on the LLS in Malaysia}

Several researches had been conducted prior to this. For instance, a study by Noor Syazana and Azlina Abdul (2020) studied the teaching of listening strategies in Malaysia. The main focus of this paper is to show a systematic review of past studies of language learning strategy in Listening skills from the year 2004 to 2016. This paper helps the readers to foster knowledge of the teaching of listening strategies during teaching and learning processes. Two research objectives were focussed in this paper such as listening models or strategies along with interventions are used to impart listening strategies during English lesson. Bottom-up processing, top-down processing, and immersive processing are three listening techniques that are often used, according to the results of this research.

Besides, Marlyna and Saazai (2016), conducted a survey of LLS of International Students. This study involves 250 international students in an institution. The survey was conducted through the questionnaire. All the items in the questionnaire were compiled from existing questionnaires and inventories of studies on OCLLSs conducted by Pickard (1996); Amin (2000); El-Saleh (2002); Zamri (2004) and Saazai (2014) and also on general LLS such as the widely-used Strategies in Language Learning (SILL) questionnaire developed by Oxford (1990). The findings of the survey showed that the respondents of this study wanted to learn the English language by viewing programmes and using resources such as technology to help them progress in the language.

Apart from that, Peter, Melor, and Mohamed Anim conducted a report on successful LLS among year 5 pupils in a school (2016). The aim of this study was to classify the LLS used by English as a Second Language (ESL) students based on four main English language skills: listening, reading, writing, and speaking. The researchers used a Language Strategy Use Questionnaire consisting of sixty statements developed from the Language Strategy Use Inventory by Cohen, Oxford and Chi (2002) as an instrument. According to the findings of this study, the respondents were moderate users of these four skills. This research offers educators with an awareness of the LLS used by learners and how it can be used to make English learning easier in their classroom.

\section{Good Language Learner}

Furthermore, in addition to LLS, researchers concentrate on Good Language Learners. According to Abdalmaujod (2013), the essential quality of a good language learner can guide the pupils to enhance their language learning efficiency. In addition, Oxford (1994) accepted Rubin and Weeden (1987) on the characteristics of successful language learners plays an important role in the field of LLS studies. There are a few characteristics of good language learners that are discussed by Rubin (1975) Stern (1975) and Rubin \& Thompson (1994) are: good language learners use proper strategies for language learning. Secondly, they organise content before they use a language. Thirdly, they usually create and like to experiment with the language in terms of grammar. On the other hand, they always create a platform to practice the language eventually and use memory strategies to recall what has been learnt.

In conclusion, the list demonstrates that successful language learners usually perform independently without relying on others and still have a constructive outlook toward language acquisition. As a result, good language learners play with their learning in their unique ways, according to their LLS. 


\section{Research Methodology \\ Research Design}

The research method adopted for this study is quantitative research which Fangyuan (2018), defines quantitative research design as an approach that investigators mostly use in developing employees' strategies of inquiry such as conducting experiments and surveys, and collecting data on predetermined instruments that yield statistical data. Since it is quantitative research, this research focused on frequencies of learning strategies used by pupils to develop their listening skills.

\section{Research Techniques}

The techniques used in this research were semi-structured interviews and surveys to collect data from the participants. A total number of 51 subjects from Year 3 took part in this research and they also contributed to the survey as well as the interview. The pupils' identities were kept anonymous. They were all intermediate pupils from a national school which is located in an urban area.

The survey used in this study is adapted from the Strategy Inventory for Language Learning (SILL). According to Fatima (2016), the SILL which is known as an effective tool for diagnostic purposes to identify the strengths and weaknesses of a person's learner's strategy use. This tool is mainly for assessing the frequency of strategy used by non-native speakers. In the SILL version, each item describes a strategy and all those items will have five-point Likert scale responses such as $1=$ never or rarely, $2=$ usually not, $3=$ sometimes, $4=$ often, 5 = always or almost always.

The semi-structured interview used also helped to increase the reliability and validity of this study. The semi-structured interview includes questions about the experience of learning strategies and how it helped them to improve their listening skill. The researchers used these two instruments to elicit pupils' self-rating on their listening skills.

\section{Research Procedure}

This study was conducted in a primary school which is located in Kuala Lumpur. A consent form was given to the parents one day before the listening class. According to Harish (2017), parental consent is required when the child is incapable of understanding the effects of taking part in a research study. Even though the children are allowed to proceed with their tasks, the approval is still needed to inform their parents or legal guardian as awareness and assurance to the school.

The selected participants attended the listening class conducted by researchers. The input was delivered to the participants. They followed the instructions given by researchers so that the teaching and learning process can be done successfully. Later, the questionnaire was given to the participants to answer. They were also guided throughout the end of the questionnaire to make sure that they understood the questions.

Then, they were brought to another classroom to conduct the semi-structured interview. An interview is considered as an important data gathering technique which involves verbal communication between the researcher and the subject (Sims \& Kunnan 2016). Data from the questionnaire were then tabulated and analysed using frequencies and percentages, while data from the semi structured interview were analysed using thematic analysis. 


\section{Findings and Discussion}

The findings showed that most of the pupils have interest when it comes to listening lessons. This can be seen from the responses collected through the questionnaire that was distributed to 51 Year 5 pupils. As shown in figure 1, 100\% from 51 respondents agreed that they like listening to English. Even though the researches did purposive sampling by choosing intermediate pupils, $19.6 \%$ of the respondents stated that they do not understand the instruction given by the teacher in English as shown in figure 2. However, 80.4\% from the respondents understood the instructions. Moreover, in figure 3,68.6\% of them practice listening outside class. It is clear that a majority of respondents are very much interested when it comes to listening English language.

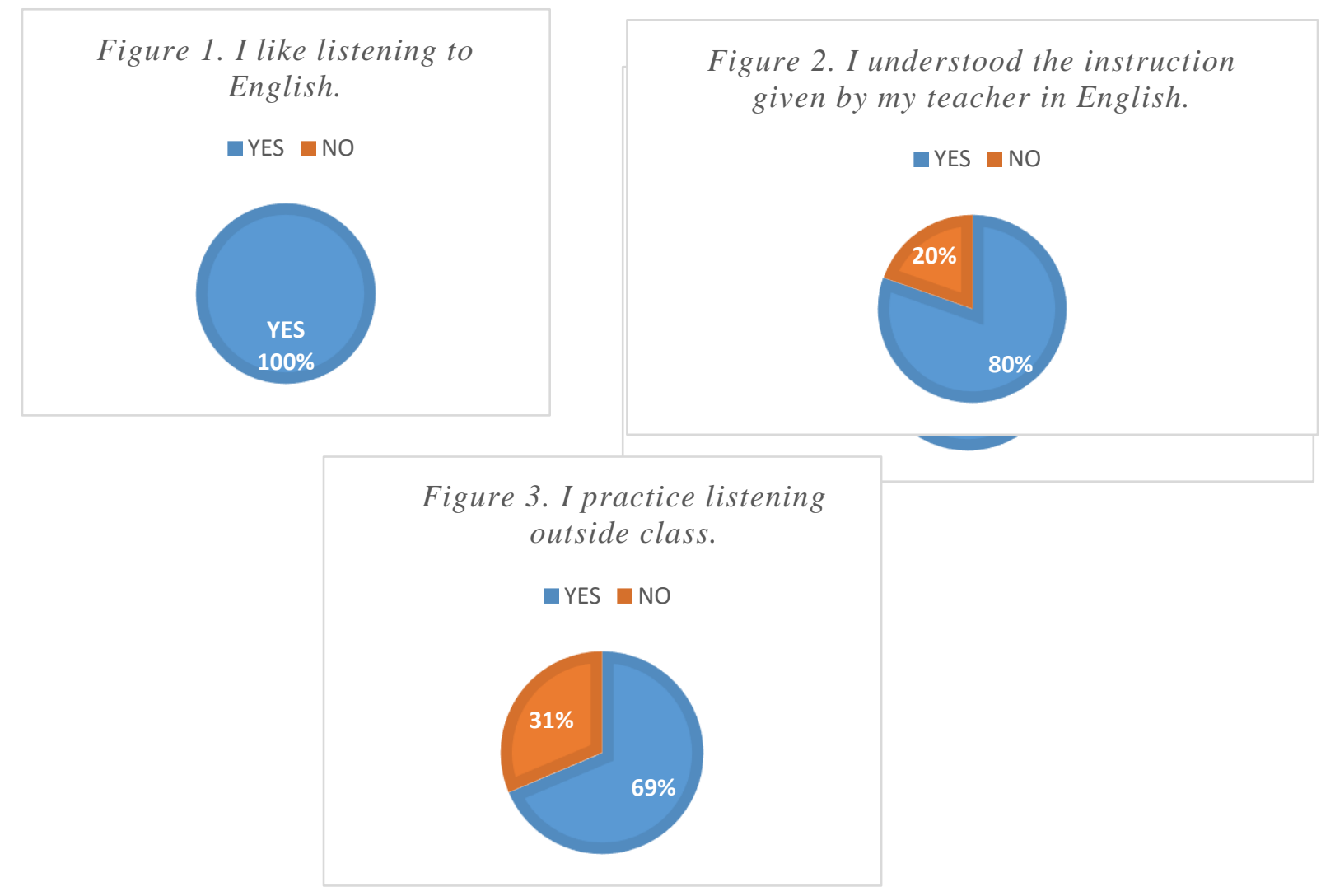

Furthermore, as the questionnaire distinguishes the questions according to Language Learning Strategies, it was easier to comprehend and find the most and least used strategies. According to table 1 , affective strategy is the most used strategy among the pupils. $88 \%$ of the respondents are self-motivated because they think listening skill is important. Listening skill is said to be an important agent in oral production by establishing a foundation for speaking in the language (Yavuz \& Celik, 2017). Therefore, through this realisation, the pupils would be able to put in some effort during the listening lessons. Moreover, the cognitive strategy also has got a number of positive responses. This is proven when $90.2 \%$ of the respondents agreed that listening to what somebody is saying improves their listening skill. Furthermore, under the cognitive strategy $76.5 \%$ of the respondents agrees that if they could not understand what a person is saying, they ask him or her to slow down or say it again. 
Table 1. The Language Learning Strategies use by the respondents (pupils).

\section{Affective Strategy}

1. I am interested in listening lessons. 96\%

2. My teacher and my friends motivate me to practice listening. $86 \%$

3. I think listening skill is important, so I am self-motivated. $88 \%$

\section{Memory Strategy}

1. I listen to talk shows on the radio, watch TV shows, or see movies $76.5 \%$ in English.

2. I listen to the language in a restaurant or store where the staff $47.1 \%$ speak English.

3. I listen to English songs or other listening scripts. $86.3 \%$

\section{Cognitive Strategy}

1. In group discussion, my listening skill improved. $66.7 \%$

2. If I cannot understand what somebody is saying, I ask him or her $76.5 \%$ to slow down or say it again.

3. Listening to what somebody is saying improves my listening skill. $90.2 \%$

\section{Metacognitive Strategy}

1. In listening, I take notes to remember ideas.

$60.8 \%$

2. After a listening practice, I check and recheck my understanding. $72.5 \%$

3. I pay special attention to difficult words while I listen and $72.5 \%$ practice.

However, the memory strategy and the metacognitive strategy have gotten lesser agreements from the respondents compared to the affective and cognitive strategy. It can be said that the pupils prefer cognitive when it comes to direct strategy and affective when it comes to indirect strategy. Although the memory strategy and metacognitive strategy collected low agreements, it is still considered high because they are all more than $50 \%$. This proves that all four strategies are effective for improving listening skill. One part in the memory strategy got $86.3 \%$ agreement from the respondents. It is that the pupils listen to English songs or other listening scripts to practice listening. This shows that pupils are very much interested to learn English through songs. It is proven that they get excited during listening lessons when associated with songs through their response in the interview session. 
Figure 4. Emerging themes that were obtained from 5 out of 51 participants during the interview session.

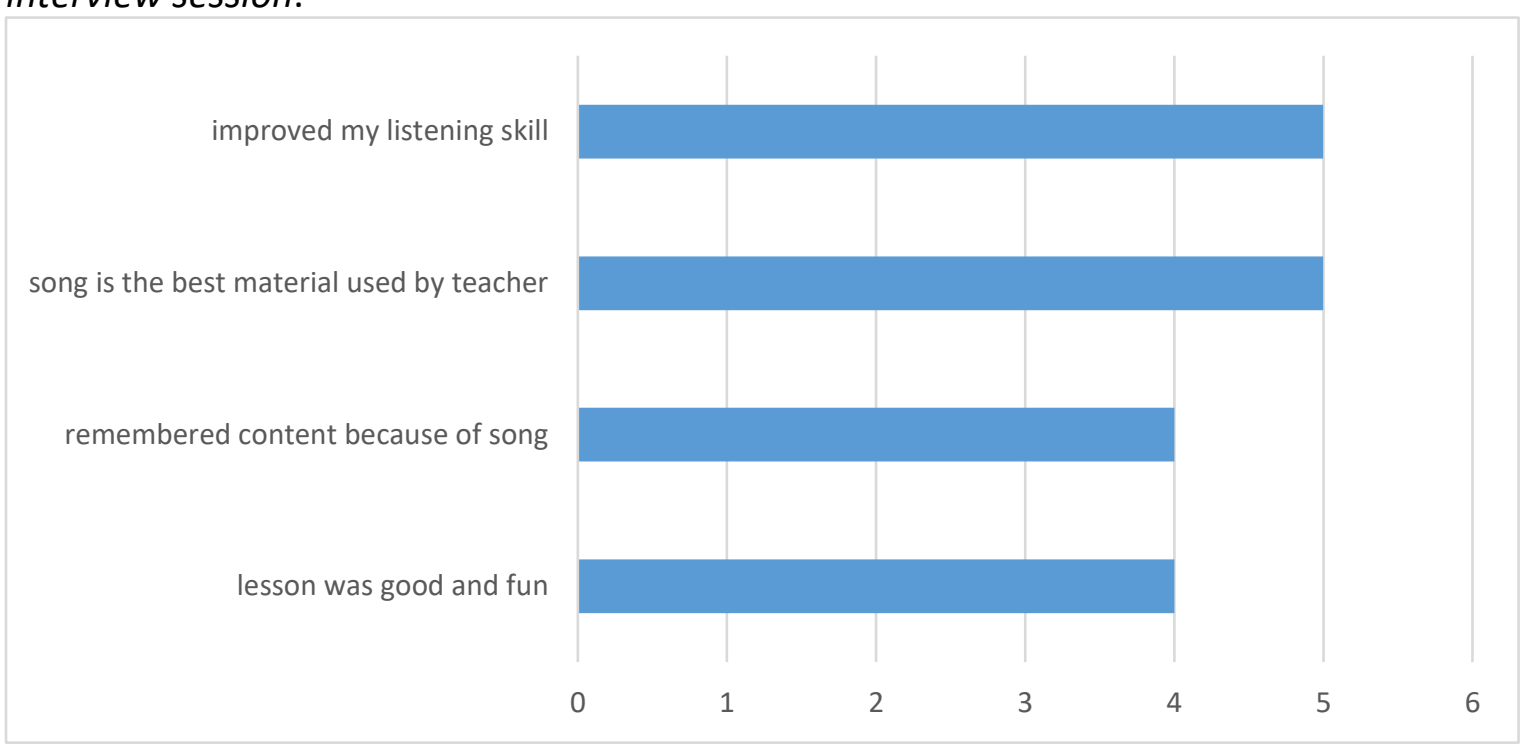

Figure 4 shows the interview results according to the frequency in which a respondent uses a word to describe his or her feelings. As depicted in figure 4, there were four positive emerging themes from the interview that was conducted. Pupils $A, B, C$ and $D$ feels good about the listening lesson and claims to have improved their listening skills as they were able to still remember the content of the lesson. The reason given by them is that they love the song and particularly Student D said that it was because the song was played again and again. Therefore, the Memory strategy seems to be very much effective for most of them. However, Pupils E said that the lesson was okay and he only remembered some parts of the content. As a whole, it can be summarised as a majority of the pupils prefer songs during listening lessons to learn the language. Therefore, songs became an exception for the pupils when it comes to memory strategy.

\section{Conclusion}

In conclusion, this paper investigates the language learning strategy suitable for and preferred by primary school pupils particularly in obtaining and improving their listening skills in English Language. Overall, it is shown they prefer the affective strategy and cognitive strategy when it comes to listening skills. However, memory strategy seems to be effective after conducting a lesson with them. Listening is a very crucial component in a certain language as it gives input for the pupils and without understanding the input, they will not be able to learn anything regarding the language (Gilakjani \& Sabouri, 2016). In order for pupils to obtain this skill particularly in English, the researchers have suggested ways to effectively improve their listening skill as good language learners. Although this paper proves that the Affective strategy and Cognitive strategy are the most practiced strategies among pupils, it also proves that the memory strategy was successful and effective after being implemented. This basically means that all four strategies are suitable in learning listening depending on the preference of the language learners themselves, in this case the pupils. Therefore, pupils should be given the exposure about the strategies and examples of learning language to make sure pupils have the choice to use one or a mixture of strategies according to their preference and ability.

Given that language learning strategies are vital today, the outcomes of this study will help the society in honing the four core skills of English Language. The increased demand for 
graduates with a background in English Language supports the need for more effective, lifechanging instructional methods. As a result, schools who use the recommended strategy based on the findings of this study will provide better training for their pupils. Therefore, pupils should be given the exposure about the strategies and examples of learning language to make sure pupils have the choice to use one or a mixture of strategies according to their preference and ability. The research will reveal crucial areas in the educational process that many researchers have yet to investigate. As a result, a new theory on language learning strategies could emerge.

\section{References}

Abdalmaujod. (2013). Language Learning Strategies: A general Overview. Procedia - Social and Behavioral Sciences, 106, 1712 - 1726.

Embi, M. A. (2000). Language Learning Strategies: A Malaysian Context. Bangi: Penerbit Universiti Kebangsaan Malaysia.

Fangyuan. (2018). Question type, language proficiency and listening strategy use: An exploratory study. Asian EFL Journal, 20(9.1), 194-213.

Fatima, I. (2016). Investigating Learning Strategies for Vocabulary Development: A Comparative Study of Two Universities of Quetta, Pakistan. Advances in Language and Literary Studies, 7(2), 2203-4714

Gilakjani, A. P., \& Sabouri, N. B. (2016). The significance of listening comprehension in English language teaching. Theory and Practice in Language Studies, 6(8), 1670-1677.

Griffiths, C. (2003). Patterns of Language Learning Strategy Use. System, 31(3), 367-383.

Harish. (2017). Informed Consent Form for Parents/Guardians of Subjects. Retrieved from https://clinicaltrials.gov/ProvidedDocs/62/NCT03422562/ICF_000.pdf

Ting, L. A. (2006). A Case Study of the Language Learning Strategies of Successful and Less Successful ESL Learners in a Suburban in Sibu, Sarawak. (Unpublished Master's Thesis). Faculty of Education, Universiti Teknologi Malaysia.

Liu, M., \& Huang, W. (2011). An exploration of foreign language anxiety and English learning motivation. Education Research International, https://doi: 10.1155/2011/493167.

Marlyna, \& Saazai, N. (2016). The Out-of-Class Language Learning Strategies of International Students in Malaysia. International Journal of Asian Social Science, 6(8), 478-486.

Ocak. (2012). Developing young learners' listening skill through song. Kastamonu Education Journal. 20(1), 327-340.

Oxford, R. (2011). Teaching and Researching Language Learning Strategies. Great Britain: Pearson Education Limited.

Oxford, R. (1990). Language Learning Strategies: What Every Teacher Should Know. New York, NY: Newbury House.

Pandian, A. (2002). English language teaching in Malaysia today. Asia-Pacific Journal of Education, 22(2), 35-52.

Rubin, J., \& Thompson, I. (1994). How to be a more Successful Language Learner (2nd Ed.). Boston: Heinle \& Heinle.

Rubin, J. (1975). What the Good Language Learner Can Teach Us. TESOL Quarterly, 9, 41-45.

Sims, J., \& Kunnan, A. (2016). Developing evidence for a validity argument for an English placement exam from multi-year test performance data. Language Testing in Asia, 6(1), 3-4. 
Ahmad, S. A., \& Razi, I. (2014). Compensation learning strategies employed by adult ESL learners of a university in Malaysia. Procedia - Social and Behavioral Sciences 90, 9(7), 85-87.

Stern, H. H. (1975). What can we Learn from the Good Language Learner? Canadian Modern Language Review, 31, 304-318.

Subramaniam, B., \& Palanisamy, K. (2014). The usage of Language Learning Strategies in Malaysian Private Secondary Schools. Advances in Language and Literary Studies, 5(4), 96-101.

Wenden. (1991). Learner Strategies for Learner Autonomy: Planning and Implementing Learner Training for Language Learners. New York, NY: Prentice Hall.

Yavuz, F., \& Celik, O. (2017). The Importance of Listening in Communication. Global Journal of Psychology Research New Trends and Issues. 7(1), 8-11.

Yoong L. K. (2010). English Language Learning Strategies used by Form Six Students in Secondary Schools. (UKM Master's Thesis). 